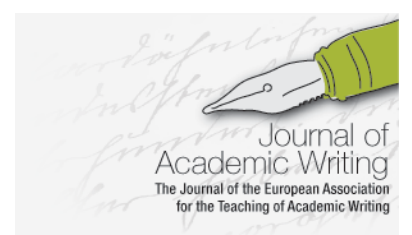

Journal of Academic Writing

Vol. 11 No 1 Summer 2021, pages 62-79

https://doi.org/10.18552/joaw.v11i1.499

\title{
Integrating Formative Assessment with Foreign Language (English) Process Writing Instruction: Lessons from Two College Writing and Reading Classes in Germany
}

\author{
Tetyana Mueller-Lyaskovets \\ Technische Universität Dortmund \\ Olena Horner \\ University of Minnesota - Twin Cities
}

\begin{abstract}
Timed single-draft essays as summative assessment tasks have been argued to be inadequate for both teaching and assessing writing in the context of process writing. This is because single draft essays assess product rather than process. To address this concern, the authors developed, implemented, and evaluated two FL (foreign language) English writing courses that integrate various formative assessment activities for teaching writing. The course-embedded evaluation methodology included three techniques: pre-testing, collecting teacher-student conference reports, and administering a student opinion survey at the end of the semester. Pre-testing and collecting conference reports were both used as techniques for simultaneous teaching and inquiry into this teaching. The student opinion survey evaluated the course design grounded in the new teaching methodology. The findings of the study indicate that consistent use of formative assessment in the English as a Foreign Language (EFL) writing class increases student confidence and motivation to develop their writing skills. Results demonstrate that academic ( $\mathrm{C} 1$ level) and college (B2 level) writing courses that integrate formative assessment into teaching process writing can be a valuable addition to an array of FL (English) language courses offered by the departments of foreign languages at European universities.
\end{abstract}

\section{Introduction}

This paper presents our study on the advantages of incorporating formative assessment into the teaching of FL (English) reading-based process writing for academic purposes. Other studies have already indicated that formative assessment, for example in a portfolio assessment classroom, can effectively facilitate the learning of writing in both EFL and English as a Second Language (ESL) writing settings (Hamp-Lyons \& Condon, 2000; Lam, 2014, 2016). Despite the benefits of formative assessment as an effective tool for the acquisition of the writing skills by EFL learners, research that details and supports its use in the EFL context remains scarce.

There is a wealth of empirical studies validating the positive impact of formative assessment on student learning, engagement, and motivation. Although providing valuable insights into the practices of formative assessment, these studies examine formative assessment in contexts other than FL (English) instruction. They deal with formative assessment in the high school L1 English instruction (Graham et al., 2011; Graham \& Sandmel, 2011; Frey \& Fisher, 2013), in the work of a writing center (Law \& Murphy, 1997), and in the teaching of a science class (Coffey et al., 2011) or a general psychology class (Weldmeskel \& Michael, 2016). Because research into formative assessment cuts across different 
fields and disciplines, it seems to overlook 'the disciplinary substance of what teachers and students assess' (Coffey et al., 2011, p. 1109).

The paper shows one way in which formative assessment can foster better writing skills in an EFL context by increasing student confidence and motivation to develop those skills. More specifically, it details how we developed, implemented, and evaluated formative assessment activities - all continuous with the disciplinary practices of teaching FL (English) college writing and academic writing at the B2 and C1 levels, respectively. Unlike studies that focus on separate strategies and forms of formative assessment of writing, such as conferencing or teacher and student feedback, our study examines formative assessment as spanning all the stages of our writing courses.

\section{Challenges in EFL assessment of writing}

As Hamp-Lyons (2007) and Lam $(2014,2016)$ convincingly show, the EFL writing pedagogy tends to be product-based and teacher-dominated. The purpose of the study is to address this incongruence between the process-based and iterative nature of writing and the practice of its product-based, summative assessment that still dominates the EFL teaching landscape.

The process writing approach has been widely acknowledged through both research and classroom instruction (Johnson, 2008; Hayes, 1996; Flower \& Hayes, 1981; Murray, 1972; Seow, 2002; Simpson, 2013). In the context of process writing, the use of summative assessment in the form of a timed singledraft essay has been argued to be inadequate for both teaching and assessing writing because it assesses the product rather than the process (Lee, 2006; Porto, 2001; Walker \& Ríu, 2008; Zhang, 2009). In 1972, in his programmic essay 'Teach Writing as a Process not Product,' Murray pointed out that product evaluation does not improve the product. Another problem with summative assessment in the form of a timed essay is that it leaves out the social interactions with a teacher or peers that the writer needs to create the final product (Carver, 2017; Porto, 2001; Prior, 1998 as cited in Lee, 2006, p. 309; Weigle, 2002; Wiggins, 1994).

To address this mismatch between the process writing and the practice of its summative assessment in FL (English) courses, we developed, implemented, and evaluated a set of formative assessment activities that, we believe, are better suited for teaching writing in an EFL classroom. This essay details how formative assessment activities were integrated with both instruction and inquiry into this instruction in our two writing courses. Our local experience of teaching college writing at a German Technical University to the FL (English) writers is informed by our conviction that writing is discovery that benefits from formative assessment.

\section{Benefits of formative assessment}

Being 'a process, not a particular test' (Popham, 2011, p. 6), formative assessment does not exclude or substitute summative assessment. Summative assessment is needed, for example, for placement purposes, whereas formative assessment is used as an intervention strategy to improve both students' writing processes and final products. As an intervention, formative assessment can be theorized as action research (Argyris et al., 1985) into one's own writing and learning, whose results are fed back into one's own work in progress with the aim of its improvement. In their theory of formative assessment, Black and Wiliam (2009, p. 9) explain:

Practice in a classroom is formative to the extent that evidence about student achievement is elicited, interpreted, and used by teachers, learners, or their peers, to make decisions about the next steps in instruction that are likely to be better, or better founded, than the decisions they would have taken in the absence of the evidence that was elicited.

Black and Wiliam (2009, p. 9) convincingly argue that formative assessment drives both teaching and learning by allowing for the identification of the weaknesses in instruction and by suggesting the ways for both teachers and learners to address them.

In terms of teaching writing, it is important to realize that formative assessment is not limited to feedback on student writing but rather is an approach integrated with instruction. To create learning through formative assessment, Black and Wiliam (2009) suggest the following formative assessment strategies: 
- Sharing success criteria with learners

- Classroom questioning

- Comment-only marking

- Peer- and self-assessment

- Formative use of summative tests. (p. 7)

All of these formative instruction strategies allow for social interaction that supports writers. In developing our writing courses, we tailored all five strategies to the specific disciplinary context of FL (English) writing.

Along with the general benefits of formative assessment discussed in formative assessment theory, our interest in formative assessment was driven by numerous studies, including meta-analysis studies, on the outcomes of formative assessment of writing. These studies found that formative assessment strategies enhance writing quality (Frey \& Fisher, 2013; Graham et al., 2011; Graham et al., 2015). Not limited to teaching writing, formative assessment provides students with the tools for self-regulated learning, which links it to students' autonomy (Black \& Wiliam, 2009, pp. 8, 13), motivation (Ryan \& Deci, 2000), and interest (Hidi \& Harackiewicz, 2000). Thus, research into formative assessment provides convincing evidence for incorporating formative assessment into teaching FL (English) writing.

Cauley and McMillan (2010, p. 2) stress the need to integrate formative assessment with instruction through the Formative Assessment Cycle. In this model, 'instructional correctives by teachers and students' affect student motivation that is directly linked to student ongoing engagement and achievement. Student ongoing engagement, in its turn, is realized through ongoing assessment and feedback - both of which take us back to instructional correctives. Our course design is grounded in the Formative Assessment Cycle as it utilizes ongoing assessment and feedback to increase student achievement by generating and supporting student motivation. In this way, we aim to promote what Cauley and McMillan (2010, p. 3) describe as mastery goals, which, in contrast to performance goals, teach students to value reflection, ongoing learning, and mastering new skills.

\section{Goals and Teaching Situation}

The goal of this research is to demonstrate the advantages of incorporating formative assessment into the teaching of FL (English) reading-based process writing for academic purposes. Informed through the course-embedded assessment approach and the scholarship of teaching and learning (SoTL) 'movement' (Breslow, 2007; Boyer, 1990; Hutchings \& Shulman, 1999; Shulman, 1999), this paper details how formative assessment can become a means for simultaneous teaching of process writing and inquiry into this teaching. Since 'The assessment of learning and teaching can be viewed as two complementary and overlapping activities that aim to benefit both the quality of student learning and the professional development of the instructor' (Carnegie Mellon University, 2019; Ogar, 2014: 30), we view student-perceived learning outcomes and students' attitudes towards the teacher's involvement as a vehicle for evaluating the success of our teaching that incorporates a new pedagogy.

We have been practicing formative assessment in the B2 Writing and Reading and C1 Academic Writing and Reading classes in the Department of Foreign Languages of a Technical University. More of an ethnographic type of a study that uses mixed methods (Creswell, 2003) to evaluate the success of the project, this study was developed to address the following three questions:

1. What are students' necessities for the writing course in terms of process writing and teacher support?

2. How do students develop their process-oriented writing skills through formative assessment activities integrated with other course assignments?

3. What aspects of our course methodology helped our students increase both their confidence in writing and their motivation to develop their writing skills beyond these courses? 
Focusing on formative assessment and its integration with teaching writing, the paper does not address the final, summative assessment of student process writing in these courses. Detailing and explaining the link between formative and summative assessment in a writing course would be a topic for a separate inquiry into learning-cum-assessment tools in an EFL writing classroom. However, to provide a context for our investigation into formative assessment practices, we would note that our student process writing in the discussed courses was assessed through portfolios that showcased the stages of the writing process. The portfolios contained one-page paper proposals, detailed outlines of the paper, the draft or drafts of the paper, and the final paper draft. The final grade for both courses splits in the following way: reading comprehension test (25\%), one-page response essay (10\%), the first draft of the paper (10\%; graded on a pass/fail basis), portfolio (50\%), and paper presentation (5\%).

\section{How we Taught the Courses}

Our writing courses were designed to address the students' insufficient awareness of writing being a process. Another goal was to foster students' awareness of formative assessment practices that allow for modifying their writing processes and products. By grounding our course design in process writing as assisted through formative assessment, we were guided by ethical considerations and teachers' responsibilities. As language teachers, we should remember that what has become a classical approach to teaching writing as prewriting, writing, and rewriting (Murray, 1972) has deep epistemological and ethical roots. By teaching writing as a process, we acknowledge that writing is a creative act and that we all are on lifelong learning trajectories. Setting the tone in 1972, Murray urged language teachers to nurture this attitude of discovery when he wrote, "We work with language in action. We share with our students the continual excitement of choosing one word instead of another, of searching for the one true word' (p. 4).

To achieve our teaching goal, we exposed our students to the formative assessment activities integrated with the writing courses. In following this goal, it was important to take the idea of writing beyond the boundaries of just grammatical correctness and the number of foreign words produced and to focus more on the strategies and structures of storytelling (Schimel, 2012). Most importantly, we wanted to convey the idea of writing as a process connected to thinking rather than a write-up of a finished study. To connect writing and thinking, we developed a series of activities based on feedback and teacher-student conversations and by creating a classroom environment that does not put an undue emphasis on grammar and spelling (Simpson, 2006, p. 100). The major steps and formative assessment activities of our classes are presented in Table 1. Table 1 also provides a holistic picture of how these formative assessment activities were integrated with other course events. While acknowledging the synergetic relationship of reading and writing in our courses, in this study, we focus on the writing component. The assigned readings for both courses served as examples for students' own essays.

By integrating formative assessment within the courses, we wanted to increase the students' motivation and confidence they need to develop their writing skills beyond these courses based on the assumption that self-efficacy ${ }^{1}$ correlates with performance (MacArthur et al., 2016). The paper showcases the results of this teaching pedagogy with regard to the students' increased motivation and confidence to write a paper.

\footnotetext{
1 The concept of self-efficacy introduced by Bandura $(1977,1986,1997)$ 'reflects confidence in the ability to exert control over one's own motivation, behavior, and social environment' (American Psychological Association, 'Teaching Tip Sheet: Self-Efficacy,' para. 1).
} 
Table 1.

Course Framework

Steps of the Writing Process

Consider reality and documented knowledge

Ground your writing in
background research

Refine your research question

Organize your ideas through

storytelling

Draft your paper

Revise your draft

Get feedback on your final draft
Instruction Topics, Major Course Assignments, and Formative Assessment Activities

Brainstorming.

Learning techniques for coming up with a research question.

Rhetorical situation. Writing for multiple audiences. Discussion.

Write a one-page response essay/rhetorical analysis essay. Graded for clarity, development, and mechanics. Formative use of summative assessment

Start reading and annotating the sources.

Learn how to use intelligently university library databases; reference management software (Citavi, etc.).

Draft your one-page paper proposal.

Present your proposal in class. Get feedback from your peers and teacher.

Practice writing a focus statement. A focus statement written early in the project gives your project a direction and saves time. Generate a hypothesis, if applicable. Try to answer your research question, if doable.

Write your paper outline. Start writing your paper from the outline. Upload your outline to the Moodle course. Peer feedback on the uploaded outline. We review several outlines in class. Teacher's feedback.

Storytelling as projected onto a traditional paper structure. Discussion.

First draft due in week 8 . Students get 10 points out of 75 if they submit it on time. Drafts are uploaded to the Moodle course. A possibility of peer feedback on the uploaded draft.

Individual conferences with the teacher. The teacher provides feedback electronically.

Students are asked to write conference reports.

Review the grading rubric and editing tips on Moodle. Apply to your paper.

Discussion 'What to do with the returned paper.'

Portfolios are due in weeks 11 and 12. Portfolios are uploaded to the Moodle course and graded. Summative assessment. Individual conferences with the teacher.

Students fill out course evaluations and the end-of-semester survey.

Note. Assessment activities are in bold type. 


\section{Methodology}

\section{Participants}

The study participants were all students who were enrolled in the B2 Writing and Reading and C1 Academic Writing and Reading courses during four semesters in 2014, 2015, 2016, and 2017 at a metropolitan technical university in Germany. The B2 Writing and Reading course was structured similarly to the $\mathrm{C} 1$ Academic Writing and Reading course, but its assignments had a reduced number of words that students had to produce during the semester. In this B2 level course, students were required to write an expository essay. In the C1 course, students wrote a small research paper. The B2 and $\mathrm{C}^{2}$ courses were heterogeneous with regards to the steps the students had to complete to write a paper and with regards to the formative assessment activities used by the teacher.

\section{Evaluation of the new approach to process writing instruction}

The mixed methods procedures used in this study followed the 'sequential exploratory strategy' (Creswell, 2003, p. 215), which consists of two phases: a phase of qualitative data collection followed by a phase of quantitative data collection. In line with this mixed methods design, the evaluation methodology of our approach to process writing instruction included three techniques: pre-testing ${ }^{3}$, collecting teacher-student conference reports, and administering a student opinion survey at the end of the semester. Pre-testing and collecting conference ${ }^{4}$ reports were both used as techniques for simultaneous teaching and inquiry into this teaching. The end-of-semester survey provided us with summative assessment measures of our teaching methodology.

For students, pre-testing was a warm-up exercise that put them into a writing mode and invited them to think about their writing processes. For teachers, pre-testing was a way to identify the students' needs for the writing courses. These needs informed teaching emphasis and instruction strategies. To pretest, we asked students to provide answers, anonymously, and in one paragraph, to one of the four questions from the list (section Pre-testing). The course grade was not contingent on the fulfillment of this assignment.

As the next step of evaluation of our approach to process writing instruction, students were asked to fill out the conference report forms after the student-teacher conference in the middle of the semester (section Collecting conference reports). We explained that our goal in asking them to jot down the afterconference notes was to (1) help students keep track of the ideas they have just discussed with the teacher, (2) help us learn how we could help students better with their work in progress, and (3) help students learn how they could help themselves better. The course grade was not contingent on the fulfillment of this assignment.

In the final phase of the study, we administered the survey $(N=13, N=13, N=10$, and $N=16)$ that was designed to obtain information about students' attitudes to the new pedagogy. The survey questions also asked students for reflections on their learning outcomes. The survey consisted of four batteries of close-ended questions and four open-ended questions. The reliability of the survey results is supported by the consistently high response rates, with $93 \%$ in $2014,54 \%$ in $2015,80 \%$ in 2016 , and $81 \%$ in 2017 . The survey was administered after the students received back their graded papers and received the final course grades. The chi-square test for given probabilities was used to determine the differences in students' responses to the questions ${ }^{5}$ (Nardi, 2006).

The analysis of the content of the open-ended survey questions as well as the content of the pre-testing essays and conference reports involved the procedures of the grounded theory (Corbin \& Strauss,

\footnotetext{
${ }^{2}$ For how the Common European Framework of References for languages (CEFR) organizes language proficiency in levels A1 to C2, see the Council of Europe website https://www.coe.int/en/web/commoneuropean-framework-reference-languages/level-descriptions

${ }^{3}$ For the role of pretests as preinstructional strategies, see Hartley and Davis (1976) and Riordan et al. (2000).

${ }^{4}$ For the survey of literature on the role of conferencing in teaching writing, see Lerner (2005).

5 Due to the small sample sizes of participants, resulting in fewer than 5 responses in a table cell, the results of the chi-square tests should be interpreted with caution.
} 
1990). Consistent with the tenets of the grounded theory (Corbin \& Strauss, 1990), the coding process included three stages: open coding, axial coding, and selective coding. During the open coding stage, we divided the data into similar groups inductively, without preset categories/themes. During the axial coding stage, we identified categories or themes that allowed us to gain insight into students' needs, learning progress, and attitudes about the new methodology. During the selective coding stage, we examined the connections between the categories/themes and integrated them in such a way that allowed for 'explicating a story from the interconnection of these categories' (Creswell, 2003, p. 191). Coding was done manually.

Both qualitative and quantitative data collection procedures followed the ethics protocol of the university the courses were taught at. All study participants signed a permission form to reproduce their writing for the purpose of research and course improvement. The participants received information on how data were stored and handled. The survey responses were provided anonymously and voluntarily. The survey was administered after the students received their final course grades to ensure that students provided unbiased responses. Students' responses were kept in the strictest confidence.

\section{Results}

The section shows the results of the evaluation of our approach to process writing instruction and explains how this evaluation was integrated as a formative assessment tool into teaching our two writing courses.

\section{Pre-testing}

Pre-testing was used as a pre-instructional strategy (Hartley \& Davis, 1976) that fulfills three functions: a) it evaluates students' writing skills, b) it elicits information about students' necessities for the writing course, and c) it 'increas[es] students' sensitivity to the learning situation' (Hartley \& Davis, 1976, p. 241) The pretest was devised as a list of four questions. Our students were asked to respond anonymously to one of these in one paragraph of approximately 250 words during the first session.

1. How much feedback would you like to have from your teacher of writing? What will you do with this feedback?

2. Describe your writing rituals.

3. Does rewriting signal a poor learner or a good one?

4. How do I time-manage my writing of a ten-page term paper?

We wanted to know whether our students were aware of the process nature of writing and whether they viewed feedback as an integral part of this process. We also wanted to know how confident our students felt about their writing. We hypothesized that the above-mentioned dimensions of writing could constitute a serious challenge for our students.

Students seldom understood writing as process writing. They saw reading as dissected from writing because they reported the first-read-and-then-write strategy ('Before writing anything I had long ago started to read all the scientific papers'). Moreover, they substituted the idea of process writing with the idea of 'structure' limited to a succession of chapters, with the introduction to be written first ('The termpaper should be divided into different chapters', 'First, I like to put an introduction about the topic'). There was no depth to the students' understanding of structure as storytelling (Schimel, 2012).

However, the student responses indicated their need for feedback when writing in English. Some answers showed that students were aware of the benefits of feedback and that they differentiated between feedback on mechanics and content ('I like feedback that is not only about the grammar but also about the topic'). However, sometimes they perceived feedback as 'correction' provided by the teacher - a habit extrapolated from the summative assessment practices onto the writing process.

\section{Conference reports}

By obtaining student-teacher conference reports in the middle of the semester, we wanted to clarify for ourselves whether our students developed more confidence and ability at writing a good quality essay 
and whether they envisioned revision of their papers. In a special form created for this purpose, we asked the students (1) to describe a question or concern they had about their work in progress and (2) to describe briefly how they planned to revise the paper after they had talked to their teacher.

Conference reports showed that students were on the right track: they were prepared to revise, and they were more aware of their writing as grounded in the following four interconnected criteria for student writing (Elander et al., 2006, p. 71): critical thinking, argument, structuring, and language. In addition, their answers demonstrated more awareness of the writing process. In terms of plans for revision, students, for example, planned to 'start the essay with a question,' to 'think about writing an extra part about the role of media,' to 'reduce wordiness overall,' or to 'check if introduction and conclusion can be read directly after each other.'

\section{End-of-semester survey: Writing courses through students' eyes}

The goal of the end-of-semester survey was to assess the innovative course design that incorporates formative assessment into the teaching paradigm. Concomitantly, students' judgments about the value of the teacher's involvement (feedback, revision) offered perspectives on the impact of formative assessment on their learning indirectly.

The first battery of questions asked students to reflect on their writing skills development as a result of the new pedagogy employed in this course. The success of the course is evidenced by the fact that none of the students strongly disagreed with the assumption that their writing skills developed through this course. Table 2 illustrates that the majority of students strongly agreed or agreed with the statement that this course helped them become better writers by teaching them specific skills. The difference between the number of students who strongly agreed and agreed versus strongly disagreed and disagreed was statistically significant for all the items in the battery (see Table 2).

The second battery of items elicited students' opinions about the topics covered by the course. In a similar fashion, as Table 3 demonstrates, the majority of students reported that the topics covered by the course were very helpful or helpful for their future academic development. The only outlier that obtained the most not very helpful responses was the topic 'writing your paper in a certain format: MLA, APA, CMS, etc.' This is probably explained by the fact that the majority of students did not have any experience in publishing in international research journals and could not evaluate the relevance of this topic adequately. Moreover, quite often German departments practice creating their own writing formats and even offering those as guidelines on their departmental websites. Statistical analysis shows that the difference between the number of students who considered that the topics were very helpful and helpful versus not at all helpful and not very helpful was statistically significant for the majority of the items in the battery, except item 3 for all years, items 1 and 5 in 2015, and item 1 in 2016 (see Table $3)$.

The third battery of items asked students to evaluate the assignments that presented the steps or building blocks of their writing project. As expected, the results in Table 4 indicate that the majority of students strongly agreed or agreed that all the proposed steps in their writing project were helpful for producing a quality final paper. The only reservation the students had was about the multimedia presentation of their essays, which can be explained by students' lack of experience in presenting and publicizing research results. However, the difference between the number of students who strongly agreed and agreed versus strongly disagreed and disagreed with the statement about the importance of multimedia presentation skills was not statistically significant in 2014 and 2015 (see Table 4).

The survey also asked questions about the importance of revision and teacher feedback for improving students' writing. The statistics presented in Tables 5 and 6 support these statements. The difference between the number of students who strongly agreed and agreed versus strongly disagreed and disagreed with both statements was statistically significant for all years.

Finally, responses to the open-ended questions testified to the success of the course in terms of knowledge gain, positive experience, and increased motivation to develop academic writing skills in the future ('I have improved so much, writing my essay and more with a fast way.' 'Much work in comparison to other English courses, but with this course I've learned the most.' 'It is very helpful and it was a great experience learning something very important for our future.'). 


\section{Table 2.}

Students' Responses to the Question 'To What Extent Do You Agree or Disagree That This Writing and Reading Course Helped You Become a Better Writer by Teaching You the Following?'

\begin{tabular}{|c|c|c|c|c|c|c|c|c|}
\hline \multirow{2}{*}{ Survey Item } & \multicolumn{4}{|c|}{2014} & \multicolumn{4}{|c|}{2015} \\
\hline & $\begin{array}{l}\text { Strongly agree } \\
(\%)\end{array}$ & $\begin{array}{l}\text { Agree } \\
(\%)\end{array}$ & $\begin{array}{l}\text { Disagree } \\
\quad(\%)\end{array}$ & $x^{2}(1)$ & $\begin{array}{l}\text { Strongly agree } \\
(\%)\end{array}$ & $\begin{array}{l}\text { Agree } \\
(\%)\end{array}$ & $\begin{array}{l}\text { Disagree } \\
\quad(\%)\end{array}$ & $X^{2}(1)$ \\
\hline To articulate the main idea (thesis) in an essay & 42 & 58 & & $12.00^{\star \star *}$ & 33 & 67 & & $6.00^{\star *}$ \\
\hline $\begin{array}{l}\text { To organize and structure your ideas and information by } \\
\text { creating an outline }\end{array}$ & 83 & 17 & & 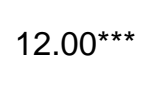 & 71 & 29 & & $7.00^{\star \star}$ \\
\hline To develop and clarify your ideas through writing projects & 50 & 50 & & $12.00^{\star \star \star}$ & 71 & 29 & & $7.00^{\star \star}$ \\
\hline To develop an argument through research and reading & 42 & 42 & 17 & $5.33^{\star \star}$ & 33 & 67 & & $6.00 * \star$ \\
\hline \multirow[t]{2}{*}{$\begin{array}{l}\text { To organize your writing process by breaking it into small } \\
\text { parts }\end{array}$} & 17 & 83 & & $12.00^{\star \star \star}$ & 17 & 83 & & $6.00^{\star *}$ \\
\hline & \multicolumn{4}{|c|}{2016} & \multicolumn{4}{|c|}{2017} \\
\hline To articulate the main idea (thesis) in an essay & 38 & 63 & & $8.00 * *$ & 31 & 69 & & $13.00^{* * *}$ \\
\hline $\begin{array}{l}\text { To organize and structure your ideas and information by } \\
\text { creating an outline }\end{array}$ & 63 & 25 & 13 & $4.50^{\star \star}$ & 54 & 46 & & $13.00^{\star * \star}$ \\
\hline To develop and clarify your ideas through writing projects & 38 & 63 & & $8.00 * *$ & 23 & 77 & & $13.00^{\star * *}$ \\
\hline To develop an argument through research and reading & 25 & 75 & & $8.00 * *$ & 31 & 46 & 23 & $3.77^{*}$ \\
\hline $\begin{array}{l}\text { To organize your writing process by breaking it into small } \\
\text { parts }\end{array}$ & 50 & 50 & & $8.00^{* *}$ & 38 & 54 & 8 & $9.31^{\star \star}$ \\
\hline
\end{tabular}

Note. Strongly disagree - 0\% for all items in 2014, 2015, 2016, and 2017.

${ }^{*} p<.10,{ }^{* *} p<.05,{ }^{* *} p<.001$. 
Table 3.

Students' Responses to the Question 'How Helpful, if at All, Were the Following Topics for Your Future Studies?'

\begin{tabular}{|c|c|c|c|c|c|c|c|c|c|}
\hline \multirow[b]{2}{*}{ Survey Item } & \multicolumn{5}{|c|}{2014} & \multicolumn{4}{|c|}{2015} \\
\hline & $\begin{array}{c}\text { Very } \\
\text { helpful } \\
(\%)\end{array}$ & $\begin{array}{l}\text { Helpful } \\
\text { (\%) }\end{array}$ & $\begin{array}{c}\text { Not very } \\
\text { helpful } \\
(\%)\end{array}$ & $\begin{array}{c}\text { Not at all } \\
\text { helpful } \\
(\%)\end{array}$ & $x^{2}(1)$ & $\begin{array}{c}\text { Very } \\
\text { helpful } \\
(\%)\end{array}$ & $\begin{array}{l}\text { Helpful } \\
\text { (\%) }\end{array}$ & $\begin{array}{c}\text { Not very } \\
\text { helpful } \\
(\%)\end{array}$ & $X^{2}(1)$ \\
\hline Audience, purpose, and genre & 25 & 58 & 17 & & $5.33^{\star \star}$ & 17 & 67 & 17 & 2.67 \\
\hline $\begin{array}{l}\text { Paragraph as a unit of writing. Topic } \\
\text { sentence. Focus statement }\end{array}$ & 64 & 27 & 9 & & $7.36^{\star \star}$ & 43 & 57 & & $7.00 \star \star$ \\
\hline $\begin{array}{l}\text { Writing your paper in a certain format: MLA, } \\
\text { APA, CMS, etc. }\end{array}$ & 25 & 42 & 25 & 8 & 1.33 & 14 & 57 & 29 & 1.29 \\
\hline Punctuation & 50 & 42 & 8 & & $8.33^{\star \star}$ & 29 & 57 & 14 & $3.57^{*}$ \\
\hline \multirow[t]{2}{*}{ Presenting your ideas in forums } & 9 & 73 & 18 & & $4.45^{\star \star}$ & 29 & 29 & 43 & 0.14 \\
\hline & \multicolumn{4}{|c|}{2016} & & \multicolumn{4}{|c|}{2017} \\
\hline Audience, purpose, and genre & & 75 & 25 & & 2.00 & 8 & 75 & 17 & $5.33^{* *}$ \\
\hline $\begin{array}{l}\text { Paragraph as a unit of writing. Topic } \\
\text { sentence. Focus statement }\end{array}$ & 63 & 25 & 13 & & $4.5^{\star \star}$ & 62 & 31 & 8 & $9.31^{\star \star}$ \\
\hline $\begin{array}{l}\text { Writing your paper in a certain format: MLA, } \\
\text { APA, CMS, etc. }\end{array}$ & & 50 & 50 & & 0 & 23 & 46 & 31 & 1.92 \\
\hline Punctuation & 50 & 50 & & & $8.00 * \star$ & 46 & 54 & & $13.00^{\star \star \star}$ \\
\hline Presenting your ideas in forums & 38 & 63 & & & $8.00 * \star$ & 23 & 69 & 8 & $9.31^{\star *}$ \\
\hline
\end{tabular}

Note. Not at all helpful - 0\% for all items in 2015, 2016, and 2017.

${ }^{\star} p<.10,{ }^{* \star} p<.05,{ }^{* \star *} p<.001$. 
Table 4.

Students' Responses to the Question 'To What Extent Do You Agree or Disagree That the Following Steps in Your Writing Project Were Helpful?'

\begin{tabular}{|c|c|c|c|c|c|c|c|c|}
\hline \multirow{2}{*}{ Survey Item } & \multicolumn{4}{|c|}{2014} & \multicolumn{4}{|c|}{2015} \\
\hline & $\begin{array}{c}\text { Strongly agree } \\
(\%)\end{array}$ & $\begin{array}{c}\text { Agree } \\
(\%)\end{array}$ & $\begin{array}{l}\text { Disagree } \\
(\%)\end{array}$ & $x^{2}(1)$ & $\begin{array}{c}\text { Strongly agree } \\
(\%)\end{array}$ & $\begin{array}{c}\text { Agree } \\
(\%)\end{array}$ & $\begin{array}{l}\text { Disagree } \\
(\%)\end{array}$ & $x^{2}(1)$ \\
\hline One-page response essay/rhetorical analysis & 45 & 55 & & $11.00^{\star \star \star}$ & 43 & 57 & & $7.00 * *$ \\
\hline Paper proposal & 58 & 33 & 8 & $8.33^{\star *}$ & 29 & 71 & & $7.00 * \star$ \\
\hline Paper proposal presentation followed by a discussion & 25 & 58 & 17 & $5.33^{\star *}$ & 43 & 43 & 14 & $3.57^{*}$ \\
\hline Paper outline & 75 & 25 & & $12.00^{\star \star \star}$ & 14 & 86 & & $7.00 * \star$ \\
\hline First draft of your essay due in week 8 & 25 & 67 & 8 & $8.33^{\star *}$ & & 67 & 33 & 0.67 \\
\hline Final draft of your essay due in week $11 / 12$ & 75 & 17 & 8 & $8.33^{\star *}$ & 43 & 57 & & $7.00^{\star *}$ \\
\hline \multirow[t]{2}{*}{ Multimedia presentation of your essay } & 33 & 33 & 33 & 1.33 & 43 & 29 & 29 & 1.29 \\
\hline & \multicolumn{4}{|c|}{2016} & \multicolumn{4}{|c|}{2017} \\
\hline One-page response essay/rhetorical analysis & 38 & 63 & & $8.00 * \star$ & 15 & 69 & 15 & $6.23^{\star \star}$ \\
\hline Paper proposal & 13 & 63 & 25 & 2.00 & 31 & 62 & 8 & $9.31^{\star *}$ \\
\hline Paper proposal presentation followed by discussion & 13 & 75 & 13 & $4.50 * *$ & 23 & 69 & 8 & $9.31^{\star *}$ \\
\hline Paper outline & 38 & 38 & 25 & 2.00 & 54 & 46 & & $13.00^{* * *}$ \\
\hline First draft of your essay due in week 8 & 50 & 25 & 25 & 2.00 & 38 & 54 & 8 & $9.31^{\star *}$ \\
\hline Final draft of your essay due in week 11/12 & 38 & 63 & & $8.00^{\star *}$ & 46 & 46 & 8 & $9.31^{\star *}$ \\
\hline Multimedia presentation of your essay & 25 & 63 & 13 & $4.50^{\star *}$ & 31 & 62 & 8 & $9.31^{\star *}$ \\
\hline
\end{tabular}

Note. Strongly disagree - 0\% for all items in 2014, 2015, 2016, and 2017.

${ }^{\star} p<.10,{ }^{\star \star} p<.05,{ }^{* \star *} p<.001$. 


\section{Table 5.}

Students' Responses to the Question 'To What Extent Do You Agree or Disagree That This Course Helped You Become a Better Writer by Emphasizing Revision as an Important Part of the Composing Process?'

\begin{tabular}{|c|c|c|c|c|}
\hline Student Responses & 2014 & 2015 & 2016 & 2017 \\
\hline Strongly agree (\%) & 50 & 50 & 50 & 31 \\
\hline Agree (\%) & 50 & 50 & 50 & 69 \\
\hline \multicolumn{5}{|l|}{ Disagree (\%) } \\
\hline \multicolumn{5}{|l|}{ Strongly disagree (\%) } \\
\hline$X^{2}(1)$ & $12.00 * * *$ & $6.00 * *$ & $8.00 * *$ & $13.00 * * *$ \\
\hline
\end{tabular}

Note. ${ }^{\star} p<.10,{ }^{\star \star} p<.05,{ }^{* \star} p<.001$.

Table 6.

Students' Responses to the Question "How Helpful, if at All, Was Your Teacher's Feedback at Each Stage of Your Composing Process?"

\begin{tabular}{lccc}
\hline \multicolumn{1}{c}{ Student Responses } & 2014 & 2015 & 2016 \\
\hline Very helpful (\%) & 67 & 43 & 63 \\
Helpful (\%) & 33 & 57 & 38 \\
Not very helpful (\%) & & & 31 \\
Not at all helpful (\%) & $12.00^{\star \star \star}$ & $7.00^{\star \star}$ & $8.00^{\star \star}$ \\
$X^{2}(1)$ & & $13.00^{\star \star \star}$ \\
\hline
\end{tabular}

Note. ${ }^{\star} p<.10,{ }^{\star \star} p<.05,{ }^{* \star} p<.001$. 


\section{Discussion}

Our research into formative assessment integrated with the instruction of FL (English) writing is aligned with studies that aim to remove the mismatch between the process-based nature of writing and the existing practice of product-oriented assessment. By requiring students to turn in portfolios that showcase their process writing, our approach shifts the emphasis towards rigorous formative assessment that spans all the stages of the course. Through the reported formative assessment activities, we provide in-process guidance and inquiry into FL (English) process writing to "produce better writers, not better writing' (North, 1984, p. 438).

We believe that it is a combination of such formative assessment events and activities as conferencing, online or in-class peer and teacher feedback, writing a paper proposal, a paper outline, and a conference report, and presenting the paper in class that increased our students' motivation to write and their confidence to develop writing beyond these courses. A holistic approach to formative assessment evident in our case study corroborates the findings of Coffey et al. (2011) who point out that good formative assessment cannot be reduced to 'strategies,' but it rather needs to be seamlessly integrated with teaching and learning because 'it is not possible to distinguish any particular strategies from activity as a whole' (p. 1129). We see our contribution to research into formative assessment and FL (English) writing in developing, implementing, and evaluating the formative assessment activities not as separate acts and events but rather as integral parts of our writing courses that permeate all stages of the writing process.

It was not only students that benefited from the integration of formative assessment into teaching writing. No less important is that our course design provided the teachers with multifarious data on their students' necessities for the writing course and on their development as writers. Such formative assessment techniques as obtaining short writing samples through pre-testing, supplementing teaching with individual student-teacher conferences, collecting conference reports, discussing grading criteria in class, or sharing drafts and providing feedback via a learning management system - all can be seamlessly integrated with teaching writing. As constituent parts of the course, they become the efficient means for both teaching and assessing the writing process because they provide both students and teachers with information they need to adjust and modify respectively their writing and teaching strategies as required. The formative assessment techniques as practiced in the discussed courses keep reminding us that, as Boyer (1990) pointed out, 'faculty, as scholars, are also learners...' (p. 24).

The first course-embedded technique - pre-testing - that was used as both an evaluation method and a formative assessment activity helped us answer our first research question about our students' necessities for the course. Students' written responses to a list of questions about process writing and formative assessment provided information about students' writing skills and delineated both students' writing habits and misconceptions about writing. Uncovering those misconceptions allowed us to better plan our intervention activities as reflected in the course topics and assignments. We organized the course as a set of prewriting, writing, and rewriting activities.

The second course-embedded technique - students' conference reports in the middle of the semester - that was again used as both an evaluation method and a formative assessment activity helped us answer our second research question about how students develop their process-oriented writing skills through our formative assessment activities. Students' written responses showed that they became more aware of the need to rewrite and that they became more aware of the higher order concerns related challenges such as focus, audience and purpose, organization, and development. As teachers, we knew that we were on the right track in terms of how we organized the course.

The third course evaluation technique - the end-of-semester survey - helped us answer our third research question. Students' responses not only showed their increased motivation and confidence to develop their writing skills but, most importantly, that they connected these intentions to the formative assessment-oriented teaching of process writing. Overall, the responses indicated that students became more confident in their ability to write an academic paper from an outline by splitting their writing into small and doable parts and by securing feedback in productive ways. Students' responses indicated their positive adaptive writing behavior such as revising multiple drafts and incorporating feedback suggestions into their drafts. The end-of-semester evaluation provided evidence that academic (C1 
level) and college (B2 level) writing courses that integrate formative assessment into teaching process writing can be a valuable addition to an array of FL (English) language courses offered by the departments of foreign languages at German universities.

Although our students complained frequently that the workload in these writing courses was heavier than in other English courses, they admitted that they learned a lot more than they did before. Our organizing the courses around the writing process as mirroring thinking and our continuous use of formative assessment techniques to inquire into one's own writing helped students understand how writing and research merge in an academic setting. We consider this raised student awareness of academic writing as inquiry and discovery to be one of the most important, far-reaching outcomes of our teaching methodology.

One of the obvious challenges regarding the reported writing courses is their meaningful placement in the curriculum. Given the emphasis these courses put on writing as a tool for learning and research, the natural drive would be to embed such writing courses into discipline-specific courses. Rather than offering them within the writing across the curriculum (WAC) paradigm, or as an add-on course (Göpferich, 2016), one could consider adapting them for the writing within the discipline (WID) approach. Although all these are meaningful recommendations, the current situation with teaching writing at German universities puts considerable restrictions on how one can teach writing. We know that writing, with rare exceptions, is not integrated into the curriculum at German universities. Most of the course participants in this study did not even require a credit from these writing courses. The absence of academic writing courses from the curriculum of other departments additionally challenged the authors to make a convincing case for adjusting teaching writing to a university culture of inquiry and continuous learning. This adjustment became possible through the integration of formative assessment tools with teaching writing. 


\section{References}

American Psychological Association (2019). Teaching Tip Sheet: Self-Efficacy. American Psychological Association. https://www.apa.org/pi/aids/resources/education/selfefficacy

Argyris, C., Putman, R., \& Smith, D. (1985). Action science. Jossey-Bass Publishers.

Badger, R., \& White, G. (2000). A process genre approach to teaching writing. ELT Journal, 54(2), 153-160.

Bandura, A. (1977). Self-efficacy: Toward a unifying theory of behavioral change. Psychological Review, 84(2), 191-215. https://doi.org/10.1037/0033-295X.84.2.191

Bandura, A. (1986). Social foundations of thought and action: a social cognitive theory. Prentice-Hall.

Bandura, A. (1997). Self-efficacy: the exercise of control. W. H. Freeman.

Black, P., \& Wiliam, D. (2009). Developing the theory of formative assessment. Educational Assessment, Evaluation and Accountability, 21(1), 5-31. https://doi.org/10.1007/s11092-008-9068-5

Boyer, E. (1990). Scholarship reconsidered: priorities of the professoriate. Special report. The Carnegie Foundation for the Advancement of Teaching.

Breslow, L. (2007). Methods of measuring learning outcomes and value added. Massachusetts Institute of Technology. https://tll.mit.edu/sites/default/files/guidelines/a-e-toolsmethods-of-measuring-learning-outcomes-grid-2.pdf

Carnegie Mellon University (2019). Conducting Assessments of Learning and Teaching. Carnegie Mellon University.

https://www.cmu.edu/teaching/designteach/teach/assesslearningteaching.html

Carver, M. (2017). Limitations of corrective feedforward: a call for resubmission practices to become learning-oriented. Journal of Academic Writing, 7(1), 1-15.

https://doi.org/10.18552/joaw.v7i1.237

Cauley, M., \& McMillan, J. (2010). Formative assessment techniques to support student motivation and achievement. The Clearing House, 83(1), 1-6.

https://doi.org/10.1080/00098650903267784

Coffey J., Hammer D., Levin D., \& Grant T. (2011). The missing disciplinary substance of formative assessment. Journal of Research in Science Teaching, 48(10), 1109-1136.

Council of Europe. (2021). Common European Framework of Reference for Languages (CEFR). Council of Europe. https://www.coe.int/en/web/common-europeanframework-reference-languages/level-descriptions

Corbin, J., \& Strauss, A. (1990). Grounded theory research: procedures, canons, and evaluative criteria. Qualitative Sociology, 13(1), 3-21.

Creswell, J. W. (2003). Research design: qualitative, quantitative, and mixed methods approaches. Sage Publications.

Elander, J., Harrington, K., Norton, L., Robinson, H., \& Reddy, P. (2006). Complex skills and academic writing: a review of evidence about the types of learning required to meet 
core assessment criteria. Assessment and Evaluation in Higher Education, 33(1), 7190 .

Göpferich, S. E. (2016). Writing centres as the driving force of programme development: from add-on writing courses to content and literacy integrated teaching. Journal of Academic Writing, 6(1), 41-58. https://doi.org/10.18552/joaw.v6i1.218

Graham, S., Harris, K., \& Hebert M. A. (2011). Informing writing: the benefits of formative assessment. A carnegie corporation time to act report. Alliance for Excellent Education.

Graham, S., Hebert M., \& Harris, K. (2015). Formative assessment and writing. A metaanalysis. The Elementary School Journal, 115(4), 523-547.

Graham, S., \& Sandmel, K. (2011). The process writing approach: a meta-analysis. The Journal of Educational Research, 104(6), 396-407. https://doi.org/10.1080/00220671.488703

Hartley, J., \& Davies, I. K. (1976). Preinstructional strategies: The role of pretests, behavioral objectives, overviews and advance organizers. Review of Educational Research, 46(2), 239-265. https://doi.org/10.3102/00346543046002239

Hutchings, P., \& Shulman, L. (1999). The scholarship of teaching: new elaborations, new developments. Change, 31(5), 10-15.

Flower, L., \& Hayes, J. R. (1981). A cognitive process theory of writing. College Composition and Communication, 32(4), 365-387.

Frey, N., \& Fisher, D. (2013). A formative assessment system for writing improvement. English Journal, 103(1), 66-71.

Hamp-Lyons, L. (2007). The impact of testing practices on teaching: Ideologies and alternatives. In J. Cummis \& C. Davison (Eds.), International handbook of English language teaching. (pp. 487-504). Springer.

Hamp-Lyons, L., \& Condon, W. (2000). Assessing the portfolio: issues for research, theory and practice. Hampton Press.

Hayes, J. R. (1996). A new framework for understanding cognition and affect in writing. In C. M. Levy \& S. Ransdell (Eds.), The science of writing: Theories, methods, individual differences and applications. (pp. 1-27). Erlbaum.

Hidi, S., \& Harackiewicz, J. (2000). Motivating the academically unmotivated: a critical issue for the $21^{\text {st }}$ century. Review of Educational Research, 70(2), 151-179.

Johnson, A. P. (2008). Teaching reading and writing: A guidebook for tutoring and remediating students. Rowman and Littlefield Education.

Lam, R. (2014). Promoting self-regulated learning through portfolio assessment: Testimony and recommendations. Assessment and Evaluation in Higher Education, 39(6), 699-714. https://doi.org/10.1080/02602938.2013.862211

Lam, R. (2016). Assessment as learning: Examining a cycle of teaching, learning, and assessment of writing in the portfolio-based classroom. Studies in Higher Education, 41(11), 1900-1917. https://doi.org/10.1080/03075079.2014.999317

Law, J., \& Murphy C. (1997). Formative assessment and the paradigms of writing center practice. The Clearing House, 71(2), 106-108. 
Lerner, N. (2005). The teacher-student writing conference and the desire for intimacy. College English, 68(2), 186-208.

MacArthur, C., Philippakos Z., \& Graham, S. (2016). A multicomponent measure of writing motivation with basic college writers. Learning Disability Quarterly, 39(1), 31-43.

Murray, D. M. (1972). Teach writing as a process not product. The Leaflet, November, 11-14.

Nardi, P. M. (2006). Doing survey research: a guide to quantitative methods (2nd ed.). Pearson Education, Inc.

North, S. M. (1984). The idea of a writing center. College English, 46(5), 433-446.

Ogar, O. J. (2014). Assessment as a veritable tool for effective teaching and learning. International Letters of Social and Humanistic Sciences, 19, 28-33. https://www.ceeol.com/search/article-detail?id=194627

Popham, W. J. (2011). Transformative assessment in action: an inside look at applying the process. ASCD.

Porto, M. (2001). Cooperative writing response groups and self-evaluation. ELT Journal, 55(1), 38-46.

Prior, P. (1998). Writing/disciplinarity: A sociohistoric account of literate activity in the academy. Lawrence Erlbaum.

Riordan, D. A., Riordan, M. P., \& Sullivan, M. C. (2000). Writing across the accounting curriculum: an experiment. Business Communication Quarterly, 63(3), 49-59.

Ryan, R., \& Deci E. (2000). Intrinsic and extrinsic motivations: Classic definitions and new directions. Contemporary Educational Psychology, 25, 54-67. https://doi.org/10.1006/ceps.1999.1020

Schimel, J. (2012). Writing science. Oxford University Press

Shulman, L. S. (1999). Taking learning seriously. Change. The Magazine of Higher Learning, July/August, 11-17.

Simpson, A. (2013). A process approach to writing. Developing Teachers.com. https://www.developingteachers.com/articles tchtraining/pw1 adam.htm

Simpson, J. (2006). Feedback on writing: Changing EFL students' attitudes. TESL Canada Journal/Revue TESL du Canada, 24(1), 96-112.

Seow, A. (2002). The writing process and process writing. In J. C. Richards \& W. A. Renandya (Eds.). Methodology in language teaching: an anthology of current practice. (pp. 315320). Cambridge University Press.

Weldmeskel, F. M., \& Michael D. J. (2016). The impact of formative assessment on selfregulated learning in university classrooms. Tuning Journal for Higher Education, 5(1), 99-118. https://doi.org/10.18543/tjhe-4(1)-2016pp99-118

Weigle, S. C. (2002). Assessing writing. Cambridge University Press

Wiggins, G. (1994). The constant danger of sacrificing validity to reliability: Making writing assessment serve writers. Assessing Writing, 1, 129-139. 
Walker R., \& Ríu C. P. (2008). Coherence in the assessment of writing skills. ELT Journal, 62(1), 18-28. https://doi.org/10.093/elt/ccmo74

Zhang, Y. (2009). Discussing the extended writing project. ELT Journal, 63(2), 167-169. 